\title{
Intracellular Delivery and Calcium Transients Generated in Sonoporation Facilitated by Microbubbles
}

\author{
Z. Fan, R. E. Kumon, J. Park, and C. X. Deng \\ Department of Biomedical Engineering, University of Michigan, 2200 Bonisteel Blvd., Ann Arbor, \\ Michigan 48109-2099, USA
}

\begin{abstract}
Ultrasound application in the presence of microbubbles is a promising strategy for intracellular delivery drug and gene, but it may also trigger other cellular responses. This study investigates the relationship between the change of cell membrane permeability generated by ultrasound-driven microbubbles and the changes in intracellular calcium concentration $\left(\left[\mathrm{Ca}^{2+}\right]_{\mathrm{i}}\right)$. Cultured rat cardiomyoblast (H9c2) cells were exposed to a single ultrasound pulse (1 MHz, 10-15 cycles, 0.27 $\mathrm{MPa}$ ) in the presence of a Definity ${ }^{\mathrm{TM}}$ microbubble. Intracellular transport via sonoporation was assessed in real time using propidium iodide (PI), while $\left[\mathrm{Ca}^{2+}\right]_{\mathrm{i}}$ and dye loss from the cells were measured with preloaded fura-2. The ultrasound exposure generated fragmentation or shrinking of the microbubble. Only cells adjacent to the ultrasound-driven microbubble exhibited propidium iodide (PI) uptake with simultaneous $\left[\mathrm{Ca}^{2+}\right]_{\mathrm{i}}$ increase and fura- 2 dye loss. The amount of PI uptake was correlated with the amount of fura- 2 dye loss. Cells with delayed $\left[\mathrm{Ca}^{2+}\right]_{\mathrm{i}}$ transients from the time of ultrasound application had no uptake of PI. These results indicate the formation of nonspecific pores in the cell membrane by ultrasound-stimulated microbubbles and the generation of calcium waves in surrounding cells without pores.
\end{abstract}

\section{Keywords}

Sonoporation; ultrasound; intracellular delivery; intracellular calcium; fast-frame photography; microbubble contrast agents; calcium imaging

\section{INTRODUCTION}

Sonoporation has shown promise to facilitate intracellular transport of drugs, proteins, genes, and other therapeutic agents that are otherwise impermeable to the cell [1-13]. Because ultrasound exposure can be non-invasively controlled in application volume and location as well as exposure duration, sonoporation is uniquely suitable for in vivo site-specific delivery $[14,15]$. However, even with recent progress in the field, a detailed mechanistic description of sonoporation and its full range of bioeffects remains to be elucidated [16].

\footnotetext{
(C) 2009 Elsevier B.V. All rights reserved.

*Corresponding author: Cheri X. Deng, Department of Biomedical Engineering, University of Michigan, 2200 Bonisteel Blvd, Ann Arbor, MI 48109-2099, USA. Tel: +1 734-936-2855; Fax: +1 734-936-1905. cxdeng@ umich.edu (C. X. Deng)..

Publisher's Disclaimer: This is a PDF file of an unedited manuscript that has been accepted for publication. As a service to our customers we are providing this early version of the manuscript. The manuscript will undergo copyediting, typesetting, and review of the resulting proof before it is published in its final citable form. Please note that during the production process errors may be discovered which could affect the content, and all legal disclaimers that apply to the journal pertain.
} 
Sonoporation is significantly enhanced by both inertial cavitation [17-20] and stable cavitation $[21,22]$, typically with microbubble ultrasound contrast agents $[23,24]$ to act as cavitation nuclei, possibly via microjetting and shock waves from collapsing bubbles [17,25,26], shear stress from microstreaming induced by bubble oscillations [21,27,28], chemical effects [29-31], and penetration of bubbles or bubble shell fragments into the cell [32].

Recent studies have demonstrated that cells treated with ultrasound with microbubbles in the medium can exhibit temporal calcium transients $[30,32,33]$. In particular, we have shown temporal calcium oscillations and spatial waves can be generated, resulting in calcium changes in cells away from the cells that directly interact with microbubbles over distances of hundreds of microns and tens of seconds after ultrasound application [34]. Because intracellular calcium is an important second messenger that regulates signal transduction and other intracellular processes, changes in the intracellular calcium ion concentration, $\left[\mathrm{Ca}^{2+}\right]_{\mathrm{i}}$, resulting from ultrasound exposure may have unintended consequences in ultrasound-mediated delivery applications such as cardiac gene transfection and targeted cancer drug delivery. However, while the aforementioned studies have suggested that calcium response occurs as a result of ultrasound application in the presence of microbubbles, it is not explicitly clear whether sonoporation of the cell membrane with intracellular delivery directly causes $\left[\mathrm{Ca}^{2+}\right]_{\mathrm{i}}$ activities.

In this study, we employ a combination of imaging techniques to determine whether sonoporation of cardiomyoblast cells and $\left[\mathrm{Ca}^{2+}\right]_{\mathrm{i}}$ changes are generated by the interaction between individual microbubbles and cells via pore formation. Ultrasound-driven microbubble activity was imaged using high-speed bright-field imaging, which was synchronized and spatially correlated with a real-time fluorescence imaging system specially designed to simultaneously measure changes in $\left[\mathrm{Ca}^{2+}\right]_{i}$ and membrane permeabilization using multiple fluorescent dyes.

\section{MATERIALS AND METHODS}

\section{Cell culturing}

H9c2 rat cardiomyoblast cells (ATCC, Manassas, VA) were grown in a humidified incubator at $37^{\circ} \mathrm{C}$ and $5 \% \mathrm{CO}_{2}$ in cell culture flasks containing the complete cell culture medium consisting of Dulbecco's modified Eagle's medium (Gibco Invitrogen, Carlsbad, CA) supplemented with $10 \%$ fetal bovine serum (HyClone, Logan, UT) and $1 \%$ penicillinstreptomycin (HyClone, Logan, UT). Two days before the sonoporation experiment, the cells were harvested from the flasks and seeded into an OptiCell ${ }^{\mathrm{TM}}$ chamber (Nunc, Rochester, NY) filled with the same cell culture medium. OptiCell ${ }^{\mathrm{TM}}$ chambers consist of two parallel, gaspermeable, cell-culture-treated, polystyrene membranes $\left(50 \mathrm{~cm}^{2}, 75 \mu \mathrm{m}\right.$ thick, $2 \mathrm{~mm}$ apart) attached to a standard microtiter plate-sized frame. At the time of experiment, the cells had reached approximately $70 \%$ confluency.

\section{Microbubble ultrasound contrast agent}

Definity ${ }^{\mathrm{TM}}$ (Lantheus Medical Imaging, Billerca, MA) consists of distributed encapsulated microbubbles, each with a $\mathrm{C}_{3} \mathrm{~F}_{8}$ gas core encapsulated by an outer phospholipid shell. Immediately after activation following the manufacturer's protocol, the suspension contains approximately $1.2 \times 10^{10}$ microbubbles $/ \mathrm{mL}$ with mean diameter range of $1.1 \mu \mathrm{m}-3.3 \mu \mathrm{m}$. However, for the current experiments, the solution was diluted with PBS to have a final concentration of $10^{6}$ microbubbles $/ \mathrm{mL}$ such that most cells had only 1 or 2 bubbles in their immediate vicinity, which was verified by direct optical observation prior to ultrasound exposure. 


\section{Measurement of intracellular calcium concentration}

Fluorescence imaging of $\left[\mathrm{Ca}^{2+}\right]_{i}$ was performed using the indicator dye fura-2 [35]. To load the dye into the cells, the cells were incubated for 60 minutes at $37^{\circ} \mathrm{C}$ and $5 \% \mathrm{CO}_{2}$ in complete cell culture medium containing $7.8 \mu \mathrm{M}$ fura-2AM (Invitrogen, Carlsbad, CA) dissolved in DMSO and $0.05 \%$ v/v of $10 \%$ w/v Pluronic F-127 (Invitrogen, Carlsbad, CA) in water. After incubation, excess dye was removed by washing the cells three times with complete culture medium before ultrasound exposure. The Opticell ${ }^{\mathrm{TM}}$ chamber was then filled with Dulbecco's Phosphate-Buffered Saline solution (DPBS, Gibco Invitrogen 14040, Carlsbad, CA), which has $\left[\mathrm{Ca}^{2+}\right]_{\mathrm{o}}=0.9 \mathrm{mM}$. Quantitative measurement of $\left[\mathrm{Ca}^{2+}\right]_{\mathrm{i}}$ was achieved via calibrated ratiometric imaging. The "raw" emitted fluorescence intensities (at $510 \mathrm{~nm}$ ) for both excitation wavelengths $340 \mathrm{~nm}$ and $380 \mathrm{~nm}$ in each cell was determined from manually segmented regions of the cell in the images. The background-corrected fluorescence intensities $\left(F_{340}, F_{380}\right)$ were obtained by subtracting the fluorescence intensity from an area free of cells from the raw intensities. The ratio $R=F_{340} / F_{380}$ was related to the change in the intracellular calcium concentration according to

$$
\left[\mathrm{Ca}^{2+}\right]_{\mathrm{i}}=K_{d} \beta \frac{R-R_{\min }}{R_{\max }-R},
$$

where the parameters $R_{\min }=0.0226, R_{\max }=0.749$, and $\beta=8.37$ were obtained by using a fura-2 calibration kit (Invitrogen F6774, Carlsbad, CA) without cells and $K_{d}=155 \mathrm{nM}$ was taken from the literature [36].

\section{Determination of membrane permeabilization with propidium iodide}

Change in cell membrane permeabilization by ultrasound was assessed by detecting the intracellular fluorescence intensity of the intercalating agent propidium iodide (PI; $668 \mathrm{Da}$ ) (Sigma Aldrich, St. Louis, MO). After loading with fura-2, PI was added to the extracellular solution to achieve a final concentration of $120 \mu \mathrm{M}$. To detect PI, the specimen was excited at $539 \mathrm{~nm}$, and emission was detected at $610 \mathrm{~nm}$. (Excitation at the ultraviolet wavelengths caused a very low-intensity emission from PI that cannot be fully distinguished from the emission from the fura-2; however, this effect is estimated to cause an error of less than 5\%.) As PI only fluoresces at these wavelengths when inside the cell, it provides a good real-time marker for delivery via membrane disruption from the extracellular solution with real-time fluorescence imaging. While irreversible changes in PI fluorescence are often used as a marker for cell death, here transient changes in PI fluorescence were also used as a marker for permeation of the cell membrane.

\section{Optical imaging and data analysis}

A schematic diagram of the experimental apparatus is shown in Fig. 1. The fura-2-loaded cells in the OptiCell ${ }^{\mathrm{TM}}$ chamber filled with the solution of PI and microbubbles were placed on a $37^{\circ} \mathrm{C}$ heating stage of an inverted microscope (Nikon Eclipse Ti-U, Melville, NY). The realtime fluorescence imaging employed a monochromator (DeltaRAM X ${ }^{\mathrm{TM}}$, PTI, Birmingham, $\mathrm{NJ}$ ) with $5 \mathrm{~nm}$ bandpass to repeatedly filter light from a $75 \mathrm{~W}$ xenon lamp at the various excitation wavelengths previously described, with an exposure time of $656 \mathrm{~ms}$ during fura-2 imaging and $400 \mathrm{~ms}$ during PI imaging. The excitation light was directed through either a 20X Super Fluor (Nikon MRF00200, Melville, NY; NA 0.75) or a 40X Plan Fluor objective (Nikon MRH08420, Melville, NY; NA 0.60) and the light subsequently emitted from the cells was passed through a polychroic filter (Chroma 73000v2, Rockingham, VT) with passbands in the green and red. The resulting series of 16 bit grayscale photomicrographs were acquired with a cooled CCD camera (Photometrics QuantEM, Tucson, AZ) at $512 \times 512$ resolution. Electron multiplication gain in the camera was set to $100 \%$ during fura- 2 imaging and $80 \%$ during PI 
imaging. The image acquisition and analysis from this camera were performed using the software package Easy Ratio Pro (PTI, Birmingham, NJ). To create the calibrated calcium images, image post-processing was performed using MATLAB (Mathworks, Natick, MA) and MetaFluor Analyst (Molecular Devices, Downingtown, PA). Noise in the regions outside the cells was suppressed by using intensity-modulated display approach [37] using the $340 \mathrm{~nm}$ images for modulation, as described previously [33]. The grayscale PI images were artificiallycolored red for display purposes by zeroing the green and blue components of each pixel.

Microbubble activity was captured using a high-speed, brightfield camera (Photron FASTCAM SA1, San Diego, CA) at a resolution of $1024 \times 1024$, rate of 5400 frames/s, and total exposure time of $\sim 2 \mathrm{~s}$. The specimen was illuminated with metal-halide light source (Dolan-Jenner MH-100, Boxborough, MA) only during the high-speed imaging.

\section{Ultrasound application and calibration}

The ultrasound system used for the experiment consisted of a non-focused circular transducer specially-designed and constructed for our study ( $1 \mathrm{MHz}$ center frequency, $0.635 \mathrm{~cm}$ diameter, Advanced Devices, Wakefield, MA). The transducer was driven by a function/waveform generator (Agilent Technologies 33250A, Palo Alto, CA) and a $75 \mathrm{~W}$ power amplifier (Amplifier Research 75A250, Souderton, PA). The transducer was characterized in free field using computer-controlled system with a $40 \mu \mathrm{m}$ calibrated needle hydrophone (Precision Acoustics HPM04/1, UK). Prior to the experiment, the transducer was aligned with the field of view of the microscope objective using a thin wire attached on the top surface of a waterfilled OptiCell ${ }^{\mathrm{TM}}$ with a plastic wall attached around its entire edge to create a small tank, which was subsequently filled with de-ionized water for acoustic energy coupling.

This alignment apparatus was then removed and replaced by the Opticell ${ }^{\mathrm{TM}}$ containing the cells loaded with fura- 2 and with PI in the extracellular medium, also with a coupling tank on top filled with deionized water. The water in the tank is physically isolated from the cells by the upper membrane of the Opticell ${ }^{\mathrm{TM}}$ chamber. The transducer was positioned such that the active surface of the ultrasound transducer submerged in solution was $\sim 7 \mathrm{~mm}$ from the cells at the bottom of the dish at an angle of approximately 45 degrees (Fig. 1). The transducer had a near field distance of $\sim 6.4 \mathrm{~mm}$ and spatial width (half-max) at $7.5 \mathrm{~mm}$, which is the approximate distance between the transducer and OptiCell ${ }^{\mathrm{TM}}$ chamber during the experiments. As such, the entire field of view of the microscope $(200 \times 200 \mu \mathrm{m}$ at $40 \mathrm{X}, 400 \times 400 \mu \mathrm{m}$ at $20 \mathrm{X})$ was insonified. The cells are attached to the top polystyrene membrane of the OptiCell ${ }^{\mathrm{TM}}$ chamber. Standing wave effects [38] due to the bottom membrane of the OptiCell ${ }^{\mathrm{TM}}$ were minimized by angling the ultrasound beam and using short pulses. The generated ultrasound waveforms at the region of interest had peak negative pressure of $0.27 \mathrm{MPa}$ as determined from the calibration above. A single ultrasound tone burst of 10 or 15 cycles was applied during each experiment.

\section{Experimental protocols}

Two protocols were used in our experiments, schematically illustrated in Fig.2. In the first protocol, the microbubbles were imaged during ultrasound application and included the following steps (1) baseline fluorescence imaging performed with sequential excitation at $340 \mathrm{~nm}, 380 \mathrm{~nm}$ and $539 \mathrm{~nm}$ for $20 \mathrm{~s}$; (2) baseline brightfield high-speed imaging performed for $10 \mathrm{~ms}$; (3) ultrasound application during the high-speed imaging; (4) fluorescence imaging continued with the same excitation sequence for up to $5 \mathrm{~min}$. Synchronization of ultrasound pulse and bright field imaging ensured that brightfield images would be acquired before, during, and after the ultrasound pulse. Immediately after the brightfield imaging was completed, the microscope was manually switched back to the fluorescence camera, which continued to run throughout the brightfield imaging to maintain a continuous time base during 
the entire duration of the experiment. Since light could only be directed to one camera at a time, the information from the fluorescent dyes is not captured during the time when the ultrasound pulse is applied and the bright field imaging is performed. There were 18 independent experiments conducted following the first protocol. In these experiments a total of 28 different cells each with one adjacent bubble were studied.

The second protocol involved only fluorescence imaging without the bright field imaging. In addition to excitations at $340 \mathrm{~nm}, 380 \mathrm{~nm}$ and $539 \mathrm{~nm}$, fluorescence imaging in the second protocol also included excitation at $360 \mathrm{~nm}$, the isosbestic wavelength of fura-2, to investigate the leakage of the pre-loaded fura- 2 out of the cell due to sonoporation of the cell membrane. At the isosbestic point of the dye, the fluorescent emission is independent of the $\left[\mathrm{Ca}^{2+}\right]_{\mathrm{i}}$. As such, this wavelength was used as a measure of fura-2 dye concentration [39-41]. A series of 15 independent experiments were conducted following the second protocol. A total of 36 cells, which showed $\left[\mathrm{Ca}^{2+}\right]_{\mathrm{i}}$ transient, were analyzed.

The isosbestic point of fura- 2 was confirmed in our experiments to be $360 \mathrm{~nm}$ by examining the emission intensities as a function of time in cells sequentially excited at $340 \mathrm{~nm}, 360 \mathrm{~nm}$, $361 \mathrm{~nm}, 362 \mathrm{~nm}, 380 \mathrm{~nm}$, and $539 \mathrm{~nm}$ (for PI excitation) as the result of ultrasound application to initiate change (increase) in $\left[\mathrm{Ca}^{2+}\right]_{\mathrm{i}}$. In the cells that did not exhibit PI uptake but with (delayed) change in $\left[\mathrm{Ca}^{2+}\right]_{\mathrm{i}}$ (e.g., as a result of a calcium wave but not pores on the membrane), the emission intensity from $360 \mathrm{~nm}$ excitation stayed unchanged, while the emission intensities from excitation at longer wavelengths increasingly resembled the response from excitation at $380 \mathrm{~nm}$ (which decreases in amplitude when $\left[\mathrm{Ca}^{2+}\right]_{\mathrm{i}}$ increases).

\section{Curve fitting}

Following a previous proposed model [42,43], the change in PI intensity due to PI uptake was fitted to a two-parameter exponential recovery function

$$
\mathrm{PI}(t)=\mathrm{PI}_{\infty}\left[1-\exp \left(-t / \tau_{P I}\right)\right]
$$

where $t=0$ is the time of the ultrasound application, $\tau_{P I}$ the characteristic PI recovery time and $\mathrm{PI}_{\infty}$ the asymptotic PI intensity. Analogously, intensity changes due to fura- 2 dye loss measured with the $360 \mathrm{~nm}$ excitation were fitted to a two-parameter exponential decay function

$$
F_{360}(t)=F_{360}^{\infty}+\left(F_{360}^{0}-F_{360}^{\infty}\right) \exp \left(-t / \tau_{F 360}\right)
$$

where $\tau_{F 360}$ is the characteristic decay time for fura-2 dye leakage and $F_{360}^{0}$ and $F_{360}^{\infty}$ are the initial fura- 2 intensity from $360 \mathrm{~nm}$ excitation before ultrasound exposure (known) and the asymptotic fura- 2 intensity at long times. Fitting was performed using the routines of the MATLAB Curve Fitting Tool using the default parameter on all data except those with signalto-noise ratios so low that meaningful fitting was not possible. Goodness-of-fit was assessed using the $R^{2}$ parameter (ratio of the sum of squares of the regression and the total sum of squares).

\section{RESULTS}

\section{Ultrasound-driven microbubble activities, sonoporation, and calcium transients}

In the set of experiments using the first protocol, microbubble dynamics were observed using the high-speed camera during the application of ultrasound while the intracellular delivery of the marker PI from the extracellular solution and the $\left[\mathrm{Ca}^{2+}\right]_{\mathrm{i}}$ response were measured using 
real-time fluorescence imaging. Control experiments with no microbubbles or no ultrasound yielded no PI uptake. Only those microbubbles that were immediately adjacent to the cell resulted in any observable changes in the cells. Figure 3 shows the results of a typical single experiment. Figures $3 \mathrm{~A}$ and $3 \mathrm{~B}$ show pre-ultrasound PI and $\left[\mathrm{Ca}^{2+}\right]_{\mathrm{i}}$ (pseudocolor) images superimposed on the brightfield image of the same field of view taken prior to the start of the fluorescence imaging and ultrasound application with the region of interest indicated by the solid while lines on the main body of two cells. Cell 2 is adjacent to a microbubble (indicated by the arrow) while Cell 1 is not. The absence of PI in cells (no red in Fig. 3A) indicates their viability with intact membrane (the extracellular solution contains PI). After initial baseline fluorescence imaging, the microscope is switched to the high-speed brightfield imaging followed by ultrasound application. Figures $3 \mathrm{C}$ and $3 \mathrm{D}$ show the mean PI fluorescence intensity and $\left[\mathrm{Ca}^{2+}\right]_{\mathrm{i}}$, respectively, as a function of time for the regions of interest corresponding to Cells 1 and 2 in Fig. 3A and 3B. The significant increase of PI intensity in Cell 2 is clearly shown in Fig.3C, indicating intracellular PI delivery via sonoporation. Figure 3D shows that the average $\left[\mathrm{Ca}^{2+}\right]_{\mathrm{i}}$ also increases significantly in Cell 2 before eventually returning to an equilibrium value. The return of the $\left[\mathrm{Ca}^{2+}\right]_{i}$ of Cell 2 to an equilibrium value suggests that the cell is still alive even though delivery has occurred. Figure $3 \mathrm{E}$ shows the ultrasound-induced stimulation of the microbubble adjacent to Cell 2. The bubble is seen to fragment into three smaller bubbles resulting from the ultrasound pulse. In contrast, both PI fluorescence intensity and the $\left[\mathrm{Ca}^{2+}\right]_{\mathrm{i}}$ are essentially unaffected for the nearby Cell 1 in the absence of bubble activities in close proximity.

\section{Spatiotemporal evolution of intracellular marker and calcium}

Figure 4 shows spatiotemporal evolution of the intracellular PI (Fig. 4A) and $\left[\mathrm{Ca}^{2+}\right]_{\mathrm{i}}$ changes (Fig. 4B), corresponding to the traces of Figs. 3C and 3D. The white lines show the of the regions of interest corresponding to Cell 1 and Cell 2 while the location of the microbubble before ultrasound is indicated by the small circle. Figure 4A shows that the PI delivery originates in the immediate vicinity of the microbubble at the time of the ultrasound application and then diffuses to the other areas of Cell 2 over the next 4 minutes, while Cell 1 is entirely unaffected. Figure $4 \mathrm{~B}$ shows that the $\left[\mathrm{Ca}^{2+}\right]_{\mathrm{i}}$ increases from less than $100 \mathrm{nM}$ to more than $500 \mathrm{nM}$ and then recovers. Again, the $\left[\mathrm{Ca}^{2+}\right]_{\mathrm{i}}$ of Cell 1 is unaffected. Taken together, Figs. 3 and 4 illustrate that PI delivery and change in $\left[\mathrm{Ca}^{2+}\right]_{\mathrm{i}}$ are spatially and temporally correlated in cell sonoporation due to an ultrasound-stimulated microbubble.

In every case of PI delivery, $\left[\mathrm{Ca}^{2+}\right]_{\mathrm{i}}$ changes also occurred simultaneously. While the individual bubble oscillations were not resolved due to limitation of the imaging frame rate relative to the ultrasound frequency, the high-speed bright field imaging clearly showed a change in the bubble after each ultrasound pulse.

The simultaneous occurrence of microbubble changes, PI uptake, and $\left[\mathrm{Ca}^{2+}\right]_{\mathrm{i}}$ transients indicates that the transient pore formation induced by the microbubble stimulation is likely the cause for the observed $\left[\mathrm{Ca}^{2+}\right]_{\mathrm{i}}$ transients.

\section{Delayed calcium transport in cells without pore formation}

While the results described above demonstrated that immediate $\left[\mathrm{Ca}^{2+}\right]_{\mathrm{i}}$ transients are correlated with PI delivery in cells affected by ultrasound-driven microbubble activities, cells with delayed $\left[\mathrm{Ca}^{2+}\right]_{\mathrm{i}}$ transients showed no PI uptake. Figure 5 shows the spatiotemporal evolution of the PI delivery (Fig. 5A) and the changes in $\left[\mathrm{Ca}^{2+}\right]_{i}$ (Fig. 5B) for five cells and corresponding time traces (Fig. 5C, D) from a single experiment. Prior to the application of ultrasound, no cells exhibited PI fluorescence and all the cells showed normal levels of $\left[\mathrm{Ca}^{2+}\right]_{\mathrm{i}}$. However, immediately after the ultrasound was applied, only Cell 1 exhibited a calcium transient with PI delivery (in red) indicating sonoporation on the right side of the cell. Subsequently, the 
nearby Cells 2-5 showed an increase in $\left[\mathrm{Ca}^{2+}\right]_{\mathrm{i}}$ with delays of $6 \mathrm{~s}, 6 \mathrm{~s}, 12 \mathrm{~s}$, and $42 \mathrm{~s}$, respectively, but exhibited no sign of PI delivery. After $140 \mathrm{~s}$, all cells had returned to their equilibrium $\left[\mathrm{Ca}^{2+}\right]_{\mathrm{i}}$ except Cell 1 . It is noted that the amplitude of the increase in $\left[\mathrm{Ca}^{2+}\right]_{i}$ in sonoporated cells is much higher than those in cells with delayed change in $\left[\mathrm{Ca}^{2+}\right]_{i}$ due to calcium waves.

\section{Concentration-gradient driven, bi-directional transport of markers and pore closure}

With clear evidence for the correlation between marker delivery, calcium changes, and microbbuble activity, a second set of experiments was performed to focus on sonoporation quantification. For a total of 36 different cells, in all but one of the cells, simultaneous PI uptake and $\left[\mathrm{Ca}^{2+}\right]_{\mathrm{i}}$ transients were observed immediately after ultrasound exposure. In one case, no PI uptake was detected but a small immediate $\left[\mathrm{Ca}^{2+}\right]_{\mathrm{i}}$ transient still occurred. It is possible that PI uptake may have still occurred but may have been below the detection threshold of our system $\left(\left[\mathrm{Ca}^{2+}\right]_{\mathrm{i}}>20.4 \mathrm{nM}\right.$ and under PI intensities $>20.4$ units $)$.

First, the effect of sonoporation on the post-ultrasound equilibrium values of the delivery marker and $\left[\mathrm{Ca}^{2+}{ }_{i}\right]$ was considered, where five minutes was empirically determined to be a sufficient time period for most cells to reach equilibrium or near-equilibrium conditions. Figure 6 shows a scatterplot of the $\left[\mathrm{Ca}^{2+}\right]_{\mathrm{i}}$ change $=\left[\mathrm{Ca}^{2+}\right]_{\mathrm{i}}(t=5 \mathrm{~min})-\left[\mathrm{Ca}^{2+}\right]_{\mathrm{i}}(t=0 \mathrm{~min})$ as a function of PI intensity change $=\mathrm{PI}(t=5 \mathrm{~min})-\mathrm{PI}(t=0 \mathrm{~min})$ from multiple experiments. The data demonstrate that the changes in PI and $\left[\mathrm{Ca}^{2+}\right]_{\mathrm{i}}$ are positively correlated (linear correlation coefficient $R=+0.91$ ), showing both that sonoporation caused marker delivery and that increased delivery resulted in increased $\left[\mathrm{Ca}^{2+}\right]_{\mathrm{i}}$ long after the ultrasound exposure had ended.

Next, the effect of sonoporation on the pre-loaded dye fura- 2 was investigated. If sonoporation creates non-specific pores, then the preloaded dye might leak out of the cell as the delivery marker PI is transported into the cell.

Figure 7A shows the typical result from sonoporated cells from a single experiment with the isosbestic point excitation included. The PI intensity increases in the cell after ultrasound application, indicating marker delivery due to pore formation. At the same time, the $\left[\mathrm{Ca}^{2+}\right]_{\mathrm{i}}$ transiently increases and then decreases to an equilibrium level.

Finally, the emission from $360 \mathrm{~nm}$ excitation decreases, implying a loss of fura-2 dye from the cell and thereby also indicating the existence of pore on the cell membrane. (Recall that the ratio of the emission intensities due to excitations at $340 \mathrm{~nm}$ and $380 \mathrm{~nm}$ is used to derive $\left[\mathrm{Ca}^{2+}\right]_{\mathrm{i}}$ and is thus essentially independent of dye concentration.)

The dashed lines on the figure (Fig. 7A) show the fit of the PI uptake to Eq. (2) $\left(\tau_{P I}=34.2 \mathrm{~s}\right.$, $\left.\mathrm{PI}_{\infty}=58.4\right)$ and fura-2 dye loss to Eq. (3) $\left(\tau_{F 360}=13.8 \mathrm{~s}, F_{360}^{\infty}=166\right)$. Figure $7 \mathrm{~B}$ shows that over multiple experiments the change in the emission intensity from the $360 \mathrm{~nm}$ excitation $F_{360}$ change $=F_{360}(t=5 \mathrm{~min})-F_{360}(t=0 \mathrm{~min})$ is negatively correlated with the PI intensity change $=\mathrm{PI}(t=5 \mathrm{~min})-\mathrm{PI}(t=0 \mathrm{~min})$ in these experiments $(R=-0.78)$, indicating that amount of marker delivery is related to the amount of dye loss. Using the fitting Eq. (2) and (3), the mean and standard deviation of the exponential recovery time constant $\tau_{P I}$ for PI was found to be $50 \pm 32 \mathrm{~s}$, while the mean and standard deviation of the exponential decay time constant $\tau_{F 360}$ for the fura- 2 dye loss was $25 \pm 15 \mathrm{~s}$. Although the exponential time constants depend on a combination of factors, the asymptotic behavior of fluorescence intensities of PI and fura-2 (excited at $360 \mathrm{~nm}$ ) suggests that the time constants reflect the resealing rate of the pores on the cell membrane. 


\section{Cell viability}

All of the cells affected by ultrasound-bubble included in this study (no data were excluded) and presented above were viable at the end of the 5 minute observation period after ultrasound application because they meet the following conditions: (1) its US-induced $\left[\mathrm{Ca}^{2+}\right]_{\mathrm{i}}$ rises and then returns to an equilibrium value (although it may not necessarily be its initial value), (2) the PI intensity reaches a stable plateau which is much lower than the PI intensities exhibited by the cells that were dead (verified by Trypan blue assay) before ultrasound application, and (3) the fura-2 emission intensity due to $360 \mathrm{~nm}$ excitation (when brightfield imaging was not performed) drops but reaches a non-zero equilibrium value that is higher than the final equilibrium fluorescence intensity exhibited by the cells that were dead before ultrasound application (confirmed by Trypan blue assay).

\section{DISCUSSION}

The goal of this study is to relate cell membrane poration and generation of calcium transients by employing an experimental setup with the combined capability of imaging the spatiotemporal changes of fura- 2 and PI simultaneously. While previous studies have employed PI for determining sonoporation $[18,21,31,44]$, have measured fluorescence intensities related to calcium concentration during sonoporation [30,45], and used fura-2 dye loss as a measure of sonoporation [44], in this study we measured the spatiotemporal PI intensity, calibrated $\left[\mathrm{Ca}^{2+}\right]_{i}$, fura-2 dye changes, together in real time (Figs. 3,4,6,7), correlated these changes for specific, individual cell-bubble interactions (Figs. 6,7), and quantitatively measured the recovery time constants and fluorescence intensities. The role of ultrasound-induced microbubble changes was verified by the acquisition of high-speed images of the same bubbles and cells, before, during, and immediately after a short ultrasound pulse (Fig. 3). While calcium waves resulting from sonoporation have been previously observed [32-34], we demonstrated explicitly that cells exhibiting $\left[\mathrm{Ca}^{2+}\right]_{\mathrm{i}}$ waves were not sonoporated themselves (Fig. 5).

Previous studies without microbubbles [45] and with microbubbles [30,34] have shown that cells increase $\left[\mathrm{Ca}^{2+}\right]_{\mathrm{i}}$ when the extracellular calcium concentration is greater than the intracellular concentration but show no change or decrease in $\left[\mathrm{Ca}^{2+}\right]_{i}$ when the cells are in medium with zero extracellular calcium. Both of these responses are consistent with $\mathrm{Ca}^{2+}$ transport into the cell through nonspecific pores, but existence of physical pores of membrane disruption, e.g., indicated by concomitant delivery of a membrane-impermeable marker from the extracellular solution, was not explicitly demonstrated. In the current study, the spatiotemporal correlation between the microbubble and change in PI fluorescence and $\left[\mathrm{Ca}^{2+}\right]_{\mathrm{i}}$ (Figs. 4,5) in sonoporated cells indicate that the ultrasound-driven microbubble is the cause for the $\left[\mathrm{Ca}^{2+}\right]_{\mathrm{i}}$ transients in these cells. However, it is possible that other intracellular mechanisms can also be triggered subsequently by the pore formation (e.g., calcium-induced calcium release), as has also been suggested by others [46]. In general, the recovery of $\left[\mathrm{Ca}^{2+}\right]_{\mathrm{i}}$ is mostly likely the result of several complex processes including active extracellular efflux, protein buffering, and storage in the sarcoplasmic reticulum and mitrochondria.

Cells with delayed $\left[\mathrm{Ca}^{2+}\right]_{\mathrm{i}}$ transients with respect to the cells with immediate $\left[\mathrm{Ca}^{2+}\right]_{\mathrm{i}}$ transients generated by ultrasound-driven microbubble as well as PI uptake showed no PI delivery (Fig. 5 ), indicating that the delayed transients are not directly due to pores on the membrane, but result from "calcium waves", as observed previously in a different cell type [33,34]. Hence $\left[\mathrm{Ca}^{2+}\right]_{\mathrm{i}}$ transients alone are not a good indicator for permeabilization in sonoporation for intracellular macromolecule delivery. Tsukamoto et al. [32] similarly have observed the existence of calcium transients delayed with the respect to the time of ultrasound application, particularly in cells adjacent to cells that exhibited membrane rupture (as determined by an irreversible decrease in the $380 \mathrm{~nm}$ excitation signal of fura-2). In studies on a variety of cells, 
$\left[\mathrm{Ca}^{2+}\right]_{i}$ transients have been shown to result from both intracellular [47] and extracellular transport of messengers [48].

A recent study showed that delivery by endocytosis can also occur as a result of ultrasound exposure, particularly for larger weight molecules (> $150 \mathrm{kDa})$. [49]. Imaging from the current study showed that the intracellular PI delivery was only seen initially at the area adjacent to the ultrasound-driven microbubble, despite the fact that the entire field of view is exposed to ultrasound. The PI fluorescence gradually became increasingly distributed inside the cell, and calcium changes also rapidly occur throughout the cell. These observations are inconsistent with the localization within vesicles that is observed in endocytotic delivery. Instead, it is more likely that ultrasound mediated intracellular delivery of PI observed in our experiments results from the passive transport of macromolecules into the cytosol through non-specific pores and/ or physical disruption of the membrane [17,21,50-55].

The mean $99 \%$ recovery times observed in our study from time-dependent measurements of marker intensities $\left(5 \tau_{P I} \approx 250 \mathrm{~s}\right.$ or $\left.5 \tau_{F 360} \approx 125 \mathrm{~s}\right)$ are somewhat slower than those observed previously in mechanical wounding of 10 to $30 \mathrm{~s}$ [39-41] of murine fibroblasts, but faster than the recovery times of $600 \mathrm{~s}$ in some electroporation experiments based on averaging over many murine myeloma cells $[42,43]$. These differences can come from a number of factors, including difference cell types, methods of membrane wounding, as well as fluorescent dye kinetics. In addition, the scatterplots of Figs. 6 and 7 suggest that there is a significant amount of variability in the sonoporation process in terms of the amount of marker delivery or loss. It is possible that inherent differences in nucleic acid distribution or concentration within the cell, intercellular variations in fura- 2 dye loading, and differences in the size and distance of the microbubbles could contribute this variability, but effects from these factors were not determined.

This study has several limitations. First, the study was performed on a single cell type. However, the results were qualitatively similar to those observed in other studies with other cell lines in regards to $\left[\mathrm{Ca}^{2+}\right]_{\mathrm{i}}$ response (Chinese hamster ovary cells $[33,34]$ ), propidium iodide changes (bovine aorta endothelial cells $[18,44]$ ), and fura-2 dye loss (bovine aorta endothelial cells [44]). Second, the study did not independently assess (e.g., by hydrophone measurements) the nature of the cavitation mechanism (i.e., stable or inertial), While the high-speed brightfield images did not have sufficiently high time resolution to conclusively determine the detailed nature of the cavitation during the pulse duration, the observation of clearly-resolvable bubble fragmentation after the ultrasound pulse in over half the experiments strongly suggests that inertial cavitation is likely to have occurred in these cases. In the remaining cases, the bubbles are usually smaller in diameter than before the ultrasound application, which may be suggestive of inertial cavitation, but the evidence is not conclusive. Other studies employing ultra-high speed imaging (millions of frames/s) have shown that inertial cavitation of shelled microbubbles can result under ultrasound conditions similar to those employed in this study (e.g., Optison [44]). Finally, an independent cell viability assay was not employed in this study. Hence it was not possible determine the long-term survival rate of sonoporated cells. However, we consider it likely that cells that recovered to a stable $\left[\mathrm{Ca}^{2+}\right]_{i}$ equilibrium value or had minimal PI uptake and fura-2 dye loss within a few minutes were likely to have survived, as has been similarly concluded by others [44].

Sonoporation has the ability to enhance the delivery of large-molecular weight drugs, genes, and proteins to cells, but pore formation in the cell membrane may also result in other cellular events such as calcium transients as well as hyperpolarization induced by calcium or stretch activation of ion channels [46,56-58]. It has been suggested that arrhythmogenic changes that have been clinically observed during echocardiography [59-61] may result from calcium transients $[30,46]$. Cardiac contractions can follow calcium-induced calcium release [62-64], 
and calcium transients and waves can be involved in arrhythmias [65-67]. Calcium waves have been found in migrating tumor cells, and an anti-metastatic drug has been shown to affect the calcium-wave properties of an invasive cancer cell line [68]. Another recent study has shown that even low-intensity ultrasound can induce excitation in neurons via activation of sodiumgated and calcium-gated ion channels [69], which may then also have implications for efforts to use ultrasound as a means to transiently permeate the blood-brain barrier. Although the exact consequences require further investigation, these cellular events could have important implications in many applications such as ultrasound mediated cardiac gene delivery and targeted cancer drug delivery and are thus worthy of further careful studies in order to develop sonoporation as a safe and robust strategy for controlled delivery of therapeutic agents.

\section{CONCLUSION}

Results from this study demonstrate that ultrasound-driven bubble activities generated pores on the cell membrane that resulted in the intracellular delivery of PI and changes in $\left[\mathrm{Ca}^{2+}\right]_{\mathrm{i}}$. The correlated PI gain and fura-2 loss observed in cells due to ultrasound application indicated concentration-gradient driven, bidirectional transport characteristic of non-specific pores created by the sonoporation. Cells with delayed $\left[\mathrm{Ca}^{2+}\right]_{\mathrm{i}}$ transients showed no PI uptake in cells, indicating calcium waves that originated from nearby sonoporated cells.

\section{Acknowledgments}

This work was supported in part by National Institutes of Health (R01CA116592 to C. X. Deng). Useful discussion with Olivia Cholewa at Invitrogen is also acknowledged.

\section{REFERENCES}

1. Ng KY, Liu Y. Therapeutic ultrasound: its application in drug delivery. Med Res Rev 2002;22(2):204223. [PubMed: 11857639]

2. Mitragotri S. Healing sound: the use of ultrasound in drug delivery and other therapeutic applications. Nat Rev Drug Discov 2005;4(3):255-260. [PubMed: 15738980]

3. Wu, J.; Nyborg, WL. Emerging therapeutic ultrasound. World Scientific; Hackensack, NJ: 2007.

4. Postema M, Gilja OH. Ultrasound-directed drug delivery. Curr Pharm Biotechnol 2007;8(6):355-361. [PubMed: 18289044]

5. Meijering BD, Henning RH, Van Gilst WH, Gavrilovic I, Van Wamel A, Deelman LE. Optimization of ultrasound and microbubbles targeted gene delivery to cultured primary endothelial cells. J Drug Target 2007;15(10):664-671. [PubMed: 18041634]

6. Frenkel V. Ultrasound mediated delivery of drugs and genes to solid tumors. Adv Drug Deliv Rev 2008;60(10):1193-1208. [PubMed: 18474406]

7. Hynynen K. Ultrasound for drug and gene delivery to the brain. Adv Drug Deliv Rev 2008;60(10): 1209-1217. [PubMed: 18486271]

8. Mayer CR, Geis NA, Katus HA, Bekeredjian R. Ultrasound targeted microbubble destruction for drug and gene delivery. Expert Opin Drug Deliv 2008;5(10):1121-1138. [PubMed: 18817517]

9. Pichon C, Kaddur K, Midoux P, Tranquart F, Bouakaz A. Recent advances in gene delivery with ultrasound and microbubbles. J Exp Nanosci 2008;3(1):17-40.

10. Li YS, Reid CN, McHale AP. Enhancing ultrasound-mediated cell membrane permeabilisation (sonoporation) using a high frequency pulse regime and implications for ultrasound-aided cancer chemotherapy. Cancer Lett 2008;266(2):156-162. [PubMed: 18367324]

11. Kamimura K, Liu D. Physical approaches for nucleic acid delivery to liver. AAPS J 2008;10(4):589_ 595. [PubMed: 19083101]

12. Suzuki R, Takizawa T, Negishi Y, Utoguchi N, Maruyama K. Effective gene delivery with novel liposomal bubbles and ultrasonic destruction technology. Int J Pharm 2008;354(12):49-55. [PubMed: 18082343] 
13. Deng, CX. Therapeutic Ultrasound: Mechanisms to Applications. Frenkel, V., editor. Nova Science Publishers; 2009. [in press]

14. Newman CM, Bettinger T. Gene therapy progress and prospects: ultrasound for gene transfer. Gene Ther 2007;14(6):465-475. [PubMed: 17339881]

15. Li YS, Davidson E, Reid CN, McHale AP. Optimising ultrasound-mediated gene transfer (sonoporation) in vitro and prolonged expression of a transgene in vivo: potential applications for gene therapy of cancer. Cancer Lett 2009;273(1):62-69. [PubMed: 18829156]

16. Campbell P, Prausnitz MR. Future directions for therapeutic ultrasound. Ultrasound Med Biol 2007;33 (4):657. [PubMed: 17343978]

17. Prentice P, Cuschieri A, Dholakia K, Prausnitz M, Campbell P. Membrane disruption by optically controlled microbubble cavitation. Nature Physics 2005;1(2):107-110.

18. Okada K, Kudo N, Niwa K, Yamamoto K. A basic study on sonoporation with microbubbles exposed to pulsed ultrasound. J Med Ultrasonics 2005;32:3-11.

19. Hallow DM, Mahajan AD, McCutchen TE, Prausnitz MR. Measurement and correlation of acoustic cavitation with cellular bioeffects. Ultrasound Med Biol 2006;32(7):1111-1122. [PubMed: 16829325]

20. Zhou Y, Cui J, Deng CX. Dynamics of sonoporation correlated with acoustic cavitation activities. Biophys J 2008;94(7):L51-53. [PubMed: 18212008]

21. van Wamel A, Kooiman K, Harteveld M, Emmer M, ten Cate FJ, Versluis M, de Jong N. Vibrating microbubbles poking individual cells: drug transfer into cells via sonoporation. J Control Release 2006;112(2):149-155. [PubMed: 16556469]

22. Forbes MM, Steinberg RL, O'Brien J, W. D. Examination of intertial cavitation of Optison in producing sonoporation of Chinese hamster ovary cells. Ultrasound Med. Biol 2008;34:2009-2018. [PubMed: 18692296]

23. Ferrara K, Pollard R, Borden M. Ultrasound microbubble contrast agents: fundamentals and application to gene and drug delivery. Annu Rev Biomed Eng 2007;9:415-447. [PubMed: 17651012]

24. Hernot S, Klibanov AL. Microbubbles in ultrasound-triggered drug and gene delivery. Adv Drug Deliv Rev 2008;60(10):1153-1166. [PubMed: 18486268]

25. Postema M, van Wamel A, Lancee CT, de Jong N. Ultrasound-induced encapsulated microbubble phenomena. Ultrasound Med Biol 2004;30(6):827-840. [PubMed: 15219962]

26. Ohl CD, Arora M, Ikink R, de Jong N, Versluis M, Delius M, Lohse D. Sonoporation from jetting cavitation bubbles. Biophys J 2006;91(11):4285-4295. [PubMed: 16950843]

27. Wu J. Shear stress in cells generated by ultrasound. Prog Biophys Mol Biol 2007;93(13):363-373. [PubMed: 16928394]

28. VanBavel E. Effects of shear stress on endothelial cells: possible relevance for ultrasound applications. Prog Biophys Mol Biol 2007;93(13):374-383. [PubMed: 16970981]

29. Rosenthal I, Sostaric JZ, Riesz P. Sonodynamic therapy--a review of the synergistic effects of drugs and ultrasound. Ultrason Sonochem 2004;11(6):349-363. [PubMed: 15302020]

30. Juffermans LJ, Dijkmans PA, Musters RJ, Visser CA, Kamp O. Transient permeabilization of cell membranes by ultrasound-exposed microbubbles is related to formation of hydrogen peroxide. Am J Physiol Heart Circ Physiol 2006;291(4):H1595-1601. [PubMed: 16632548]

31. Okada K, Kudo N, Kondo T, Yamamoto K. Contributions of mechanical and sonochemical effects to cell membrane damage induced by single-shot pulsed ultrasound with adjacent microbubbles. $\mathrm{J}$ Med Ultrason 2008;35(4):169-176.

32. Tsukamoto, A.; Yasui, N.; Watanabe, Y.; Furukawa, K.; Ushida, T. Sixth IASTED International Conference. Hierlemann, A., editor. Vol. 601. Acta Press; Innsbruck, Austria: 2008. p. 334-337.

33. Kumon RE, Aehle M, Sabens D, Parikh P, Kourennyi D, Deng CX. Ultrasound-induced calcium oscillations and waves in Chinese hamster ovary cells in the presence of microbubbles. Biophys J. 2007

34. Kumon RE, Aehle M, Sabens D, Parikh P, Han YW, Kourennyi D, Deng CX. Spatiotemporal effects of sonoporation measured by real-Time calcium imaging. Ultrasound Med Biol 2009;35:494-506. [PubMed: 19010589] 
35. Grynkiewicz G, Poenie M, Tsien RY. A new generation of $\mathrm{Ca}^{2+}$ indicators with greatly improved fluorescence properties. J Biol Chem 1985;260(6):3440-3450. [PubMed: 3838314]

36. Hong SJ. Mechanism of endothelin-1-induced cytosolic $\mathrm{Ca}^{2+}$ mobility in cultured $\mathrm{H} 9 \mathrm{c} 2$ myocardiac ventricular cells. Cell Signal 2002;14(10):811-817. [PubMed: 12135702]

37. Tsien RY, Harootunian AT. Practical design criteria for a dynamic ratio imaging system. Cell Calcium 1990;11(23):93-109. [PubMed: 2354507]

38. Kinoshita M, Hynynen K. Key factors that affect sonoporation efficiency in in vitro settings: the importance of standing wave in sonoporation. Biochem Biophys Res Commun 2007;359(4):860865. [PubMed: 17568561]

39. Steinhardt RA, Bi G, Alderton JM. Cell membrane resealing by a vesicular mechanism similar to neurotransmitter release. Science 1994;263(5145):390-393. [PubMed: 7904084]

40. Togo T, Alderton JM, Bi GQ, Steinhardt RA. The mechanism of facilitated cell membrane resealing. J Cell Sci 1999;112(Pt 5):719-731. [PubMed: 9973606]

41. Togo T, Krasieva TB, Steinhardt RA. A decrease in membrane tension precedes successful cellmembrane repair. Mol Biol Cell 2000;11(12):4339-4346. [PubMed: 11102527]

42. Sukhorukov VL, Djuzenova CS, Frank H, Arnold WM, Zimmermann U. Electropermeabilization and fluorescent tracer exchange: the role of whole-cell capacitance. Cytometry 1995;21(3):230-240. [PubMed: 8582245]

43. Djuzenova CS, Zimmermann U, Frank H, Sukhorukov VL, Richter E, Fuhr G. Effect of medium conductivity and composition on the uptake of propidium iodide into electropermeabilized myeloma cells. Biochim Biophys Acta 1996;1284(2):143-152. [PubMed: 8914578]

44. Kudo N, Okada K, Yamamoto K. Sonoporation by single-shot pulsed ultrasound with microbubbles adjacent to cells. Biophys J 2009;96(12):4866-4876. [PubMed: 19527645]

45. Honda H, Kondo T, Zhao QL, Feril LB Jr. Kitagawa H. Role of intracellular calcium ions and reactive oxygen species in apoptosis induced by ultrasound. Ultrasound Med Biol 2004;30(5):683-692. [PubMed: 15183235]

46. Juffermans LJ, Kamp O, Dijkmans PA, Visser CA, Musters RJ. Low-intensity ultrasound-exposed microbubbles provoke local hyperpolarization of the cell membrane via activation of $\mathrm{BK}(\mathrm{Ca})$ channels. Ultrasound Med Biol 2008;34(3):502-508. [PubMed: 17993242]

47. Boitano S, Dirksen ER, Sanderson MJ. Intercellular propagation of calcium waves mediated by inositol trisphosphate. Science 1992;258(5080):292-295. [PubMed: 1411526]

48. Sauer H, Hescheler J, Wartenberg M. Mechanical strain-induced $\mathrm{Ca}^{2+}$ waves are propagated via ATP release and purinergic receptor activation. Am J Physiol Cell Physiol 2000;279(2):C295-307. [PubMed: 10912995]

49. Meijering BD, Juffermans LJ, van Wamel A, Henning RH, Zuhorn IS, Emmer M, Versteilen AM, Paulus WJ, van Gilst WH, Kooiman K, de Jong N, Musters RJ, Deelman LE, Kamp O. Ultrasound and microbubble-targeted delivery of macromolecules is regulated by induction of endocytosis and pore formation. Circ Res 2009;104(5):679-687. [PubMed: 19168443]

50. Ross JP, Cai X, Chiu JF, Yang J, Wu J. Optical and atomic force microscopic studies on sonoporation. J Acoust Soc Am 2002;111(3):1161-1164. [PubMed: 11931292]

51. Mehier-Humbert S, Bettinger T, Yan F, Guy RH. Plasma membrane poration induced by ultrasound exposure: implication for drug delivery. J Control Release 2005;104(1):213-222. [PubMed: 15866347]

52. Schlicher RK, Radhakrishna H, Tolentino TP, Apkarian RP, Zarnitsyn V, Prausnitz MR. Mechanism of intracellular delivery by acoustic cavitation. Ultrasound Med Biol 2006;32(6):915-924. [PubMed: 16785013]

53. Duvshani-Eshet M, Baruch L, Kesselman E, Shimoni E, Machluf M. Therapeutic ultrasoundmediated DNA to cell and nucleus: bioeffects revealed by confocal and atomic force microscopy. Gene Ther 2006;13(2):163-172. [PubMed: 16177822]

54. Duvshani-Eshet M, Adam D, Machluf M. The effects of albumin-coated microbubbles in DNA delivery mediated by therapeutic ultrasound. J Control Release 2006;112(2):156-166. [PubMed: 16632040]

55. Yang F, Gu N, Chen D, Xi X, Zhang D, Li Y, Wu J. Experimental study on cell self-sealing during sonoporation. J Control Release 2008;131(3):205-210. [PubMed: 18727944] 
56. Tran TA, Roger S, Le Guennec JY, Tranquart F, Bouakaz A. Effect of ultrasound-activated microbubbles on the cell electrophysiological properties. Ultrasound Med Biol 2007;33(1):158-163. [PubMed: 17189059]

57. Tran TA, Le Guennec JY, Bougnoux P, Tranquart F, Bouakaz A. Characterization of cell membrane response to ultrasound activated microbubbles. IEEE Trans Ultrason Ferroelectr Freq Control 2008;55(1):43-49. [PubMed: 18334312]

58. Tran TA, Le Guennec JY, Babuty D, Bougnoux P, Tranquart F, Bouakaz A. On the Mechanisms of Ultrasound Contrast Agents-Induced Arrhythmias. Ultrasound Med Biol. 2009 (in press).

59. van Der Wouw PA, Brauns AC, Bailey SE, Powers JE, Wilde AA. Premature ventricular contractions during triggered imaging with ultrasound contrast. J Am Soc Echocardiogr 2000;13(4):288-294. [PubMed: 10756246]

60. Chapman S, Windle J, Xie F, McGrain A, Porter TR. Incidence of cardiac arrhythmias with therapeutic versus diagnostic ultrasound and intravenous microbubbles. J Ultrasound Med 2005;24(8):1099_ 1107. [PubMed: 16040825]

61. Dalecki D, Rota C, Raeman CH, Child SZ. Premature cardiac contractions produced by ultrasound and microbubble contrast agents in mice. Acoust. Res. Lett. Online (ARLO) 2005;6:221-226.

62. ter Keurs HE, Wakayama Y, Sugai Y, Price G, Kagaya Y, Boyden PA, Miura M, Stuyvers BD. Role of sarcomere mechanics and $\mathrm{Ca} 2+$ overload in $\mathrm{Ca} 2+$ waves and arrhythmias in rat cardiac muscle. Ann N Y Acad Sci 2006;1080:248-267. [PubMed: 17132788]

63. Chen PS, Tan AY. Autonomic nerve activity and atrial fibrillation. Heart Rhythm 2007;4(3 Suppl):S61-64. [PubMed: 17336887]

64. Dibb KM, Graham HK, Venetucci LA, Eisner DA, Trafford AW. Analysis of cellular calcium fluxes in cardiac muscle to understand calcium homeostasis in the heart. Cell Calcium 2007;42(45):503512. [PubMed: 17509680]

65. Stuyvers BD, Boyden PA, ter Keurs HE. Calcium waves: physiological relevance in cardiac function. Circ Res 2000;86(10):1016-1018. [PubMed: 10827129]

66. Honjo H, Boyett MR, Niwa R, Inada S, Yamamoto M, Mitsui K, Horiuchi T, Shibata N, Kamiya K, Kodama I. Pacing-induced spontaneous activity in myocardial sleeves of pulmonary veins after treatment with ryanodine. Circulation 2003;107(14):1937-1943. [PubMed: 12668519]

67. Chou CC, Nihei M, Zhou S, Tan A, Kawase A, Macias ES, Fishbein MC, Lin SF, Chen PS. Intracellular calcium dynamics and anisotropic reentry in isolated canine pulmonary veins and left atrium. Circulation 2005;111(22):2889-2897. [PubMed: 15927973]

68. Huang JB, Kindzelskii AL, Clark AJ, Petty HR. Identification of channels promoting calcium spikes and waves in HT1080 tumor cells: their apparent roles in cell motility and invasion. Cancer Res 2004;64(7):2482-2489. [PubMed: 15059902]

69. Tyler WJ, Tufail Y, Finsterwald M, Tauchmann ML, Olson EJ, Majestic C. Remote excitation of neuronal circuits using low-intensity, low-frequency ultrasound. PLoS ONE 2008;3(10):e3511. [PubMed: 18958151] 


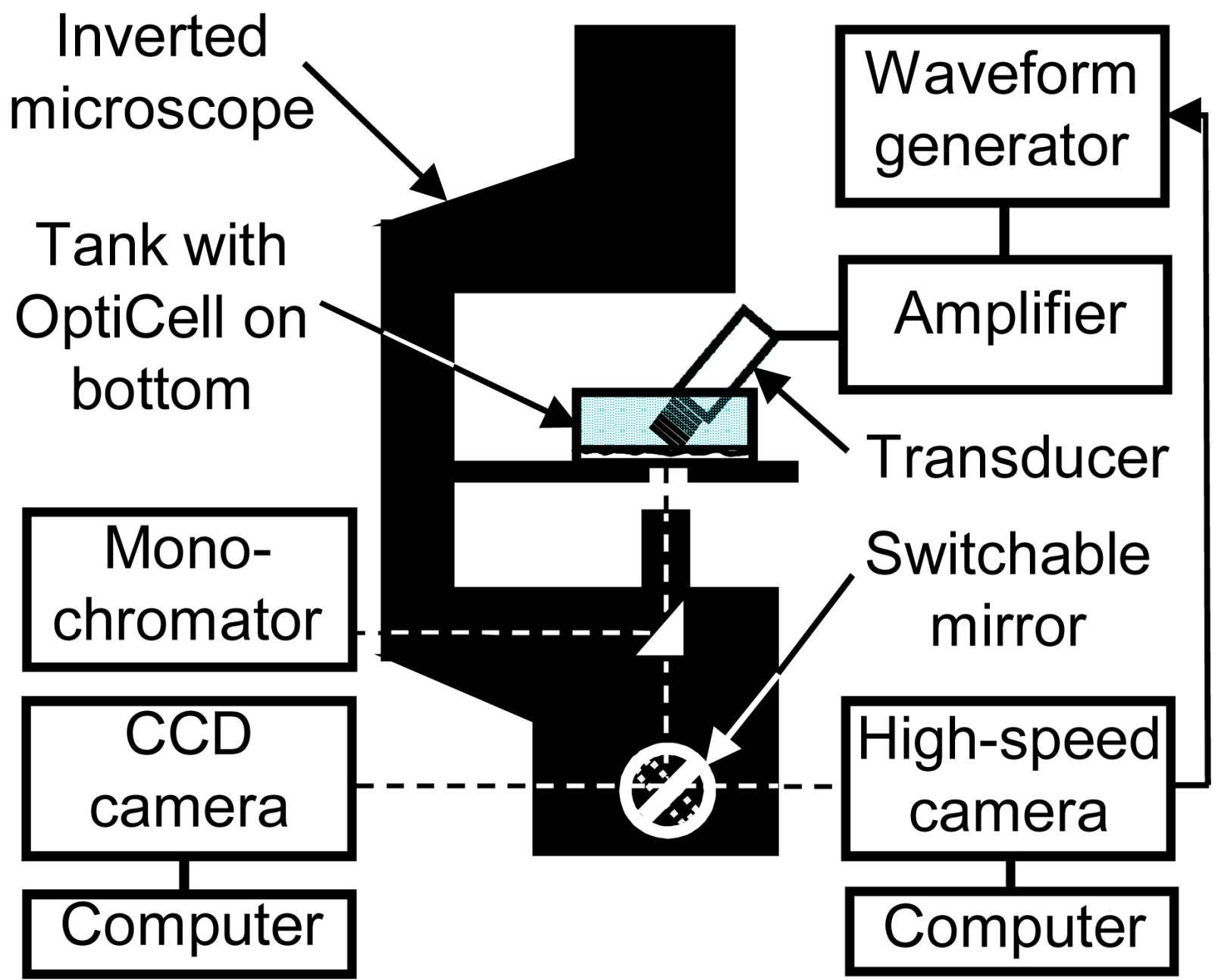

Figure 1.

Schematic diagram of experimental apparatus for spatiotemporal measurements of intracellular delivery of fluorescent marker and calcium transients generated by ultrasound-driven microbubble activities. 
A Fluorescence imaging

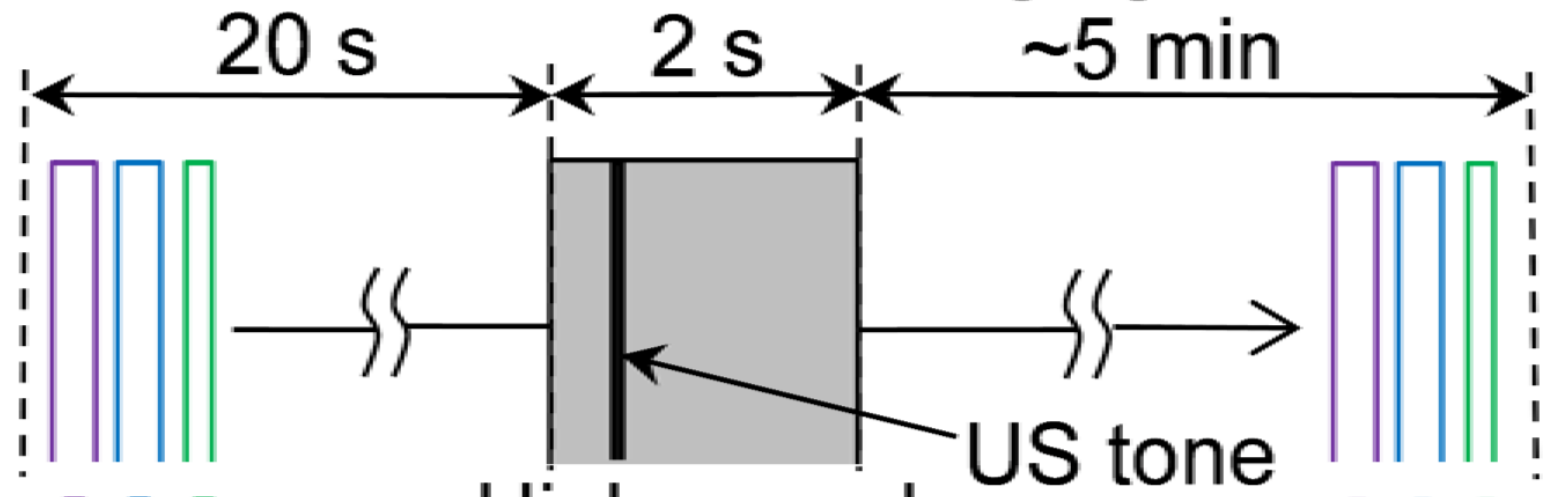

High-speed

images

burst

$(10 \mu \mathrm{s})$ $\bigcirc \bigcirc \bigcirc$

$+\infty \mathrm{m}$ ल

\section{B Fluorescence imaging}

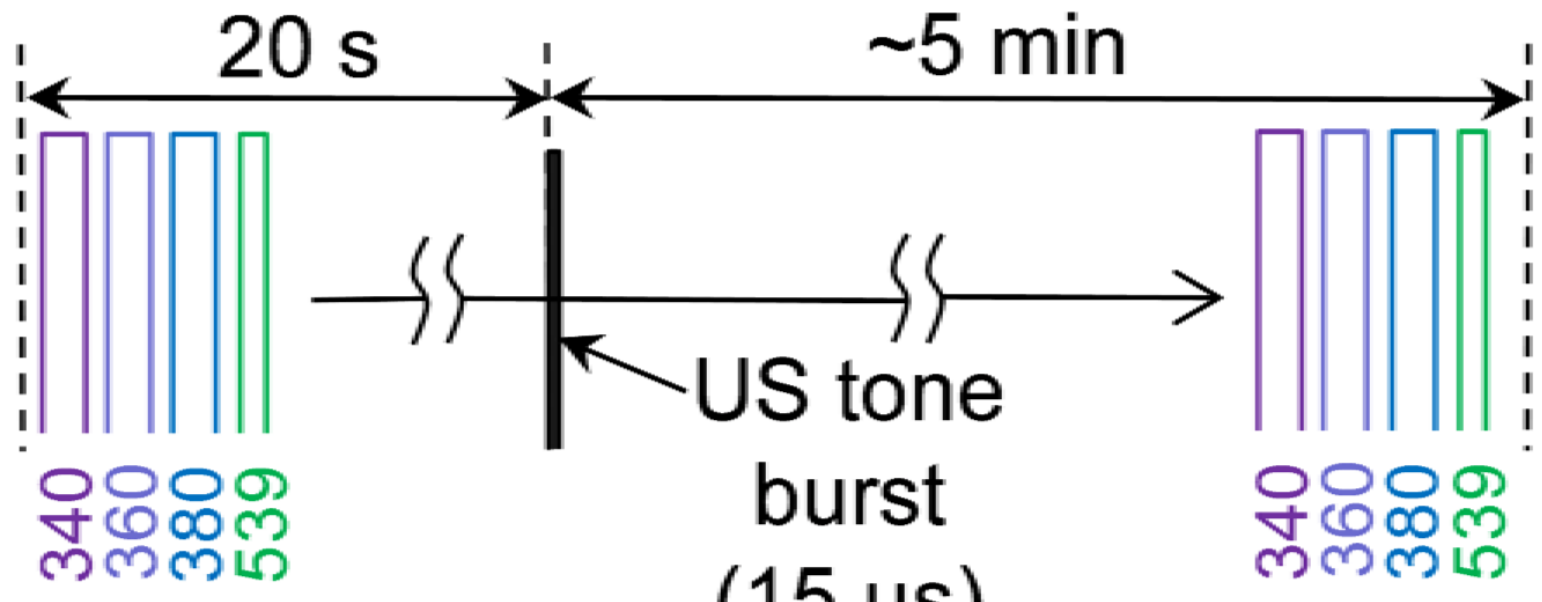

$(15 \mu \mathrm{s})$

Figure 2.

Schematic diagram of experimental protocols for monitoring intracellular delivery and calcium transients generated by ultrasound-driven microbubbles. 

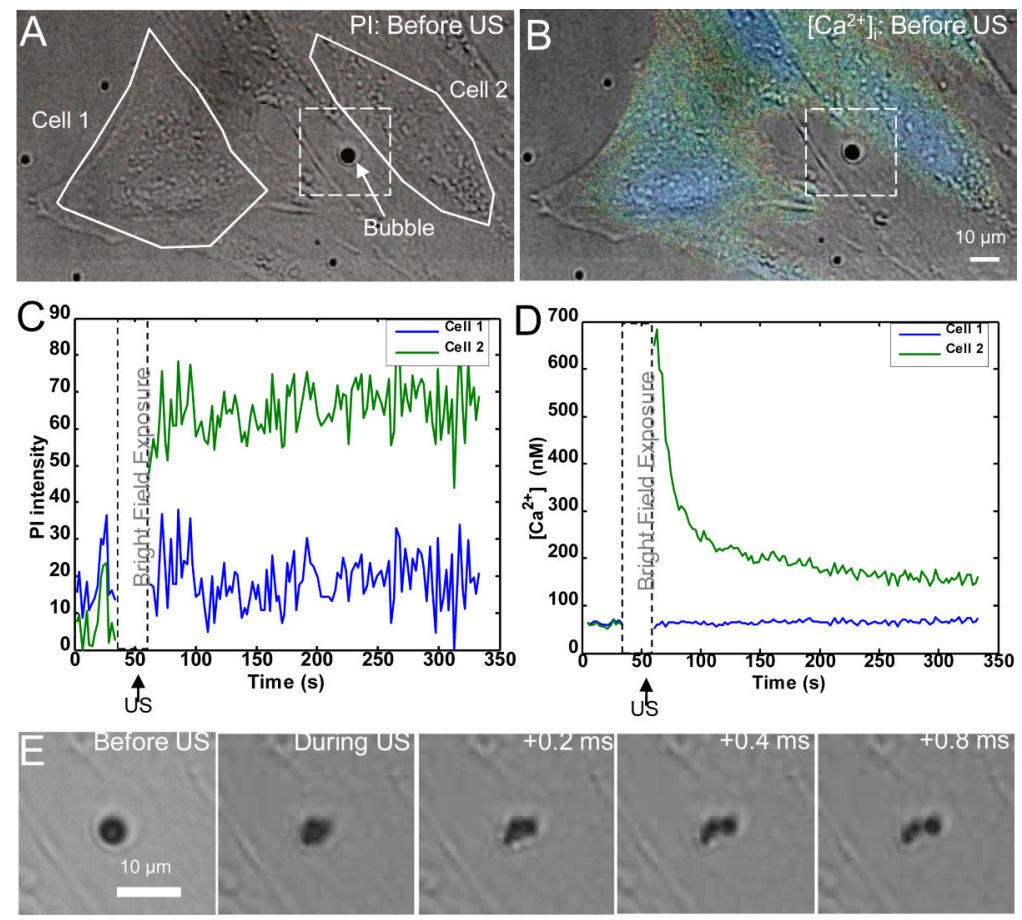

Figure 3.

Propidium iodide (PI) delivery and intracellular $\left[\mathrm{Ca}^{2+}\right]_{i}$ transients are temporally correlated with ultrasound-driven microbubbles. (A) Brightfield image with superimposed PI fluorescence image before ultrasound application. No PI is observed in the cells. The solid lines show two regions of interest within cells (Cell 1 and Cell 2). The arrow points the microbubble next to Cell 2. (B) Brightfield image with superimposed pseudocolor $\left[\mathrm{Ca}^{2+}\right]_{\mathrm{i}}$ image, indicating the initial $\left[\mathrm{Ca}^{2+}\right]_{\mathrm{i}}$ distribution before ultrasound application. (C) PI fluorescence intensity changes (from the baseline) as a function of time for Cells 1 and 2 induced by ultrasound simulation of the microbubbles. (D) $\left[\mathrm{Ca}^{2+}\right]_{i}$ changes for Cells 1 and 2 as a function of time. In $\mathrm{C}$ and $\mathrm{D}$, the break indicates the period when light was directed to the high speed camera. (E) High-speed camera recordings of the ultrasound-driven microbubble inside the dashed frames in (A) and (B) showing bubble fragmentation. 

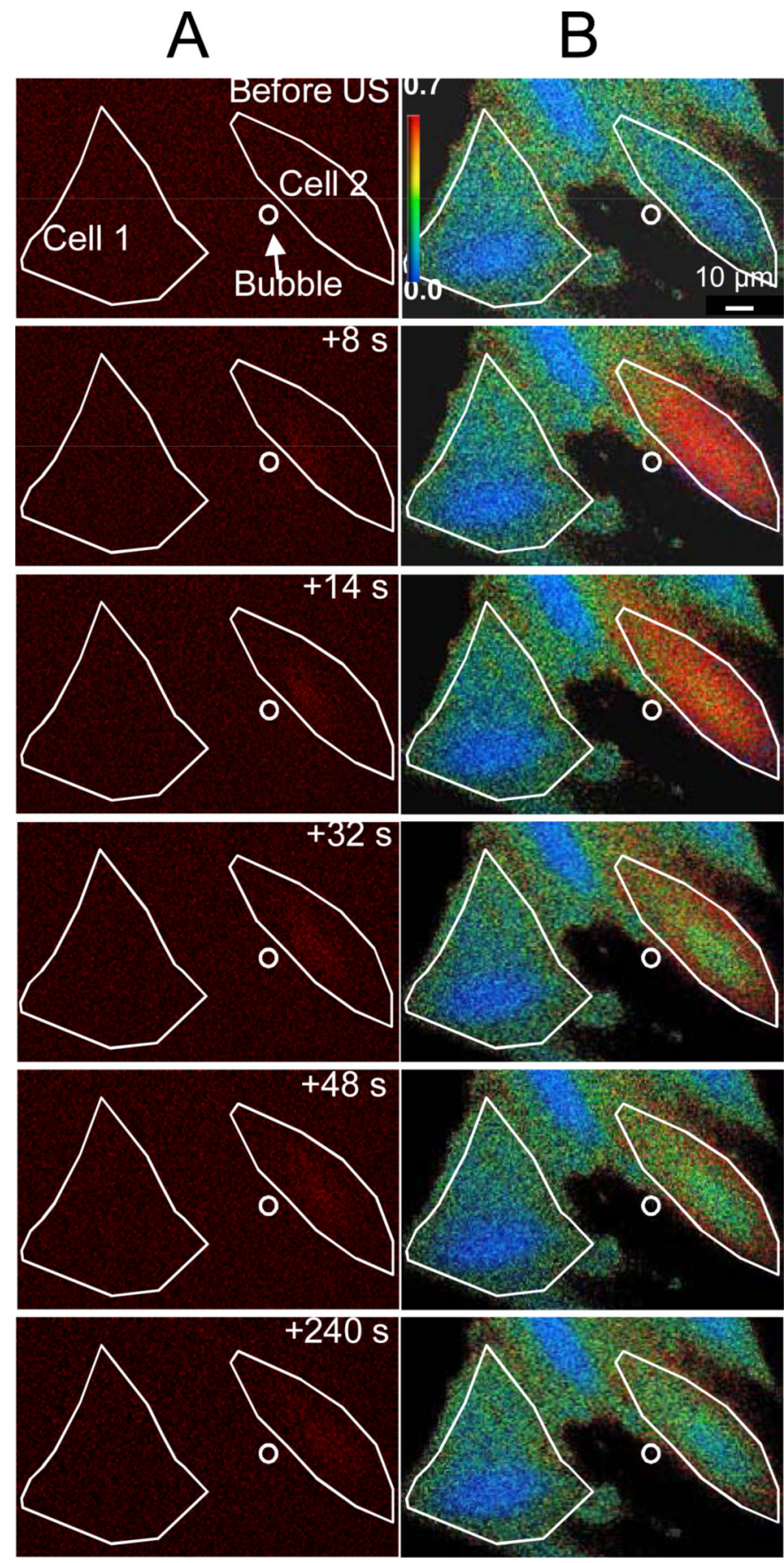

Figure 4.

Intracellular delivery of propidium iodide (PI) and intracellular $\left[\mathrm{Ca}^{2+}\right]_{\mathrm{i}}$ transients are spatially correlated with stimulation of microbubbles by ultrasound. (A) Time-lapse PI fluorescence images and (B) pseudocolor $\left[\mathrm{Ca}^{2+}\right]_{\mathrm{i}}$ images, corresponding to the traces shown in Fig. $3 \mathrm{C}$ and $\mathrm{D}$ respectively. The solid lines show the two regions of interest (Cell 1 and Cell 2), while the circle outlines microbubble next to Cell 2 at the beginning of the experiment. The color bar indicates the $\left[\mathrm{Ca}^{2+}\right]_{\mathrm{i}}$ in $\mathrm{nM}$. The first row shows the cells before ultrasound exposure while the subsequent rows show the cells at the indicated times after ultrasound application. 

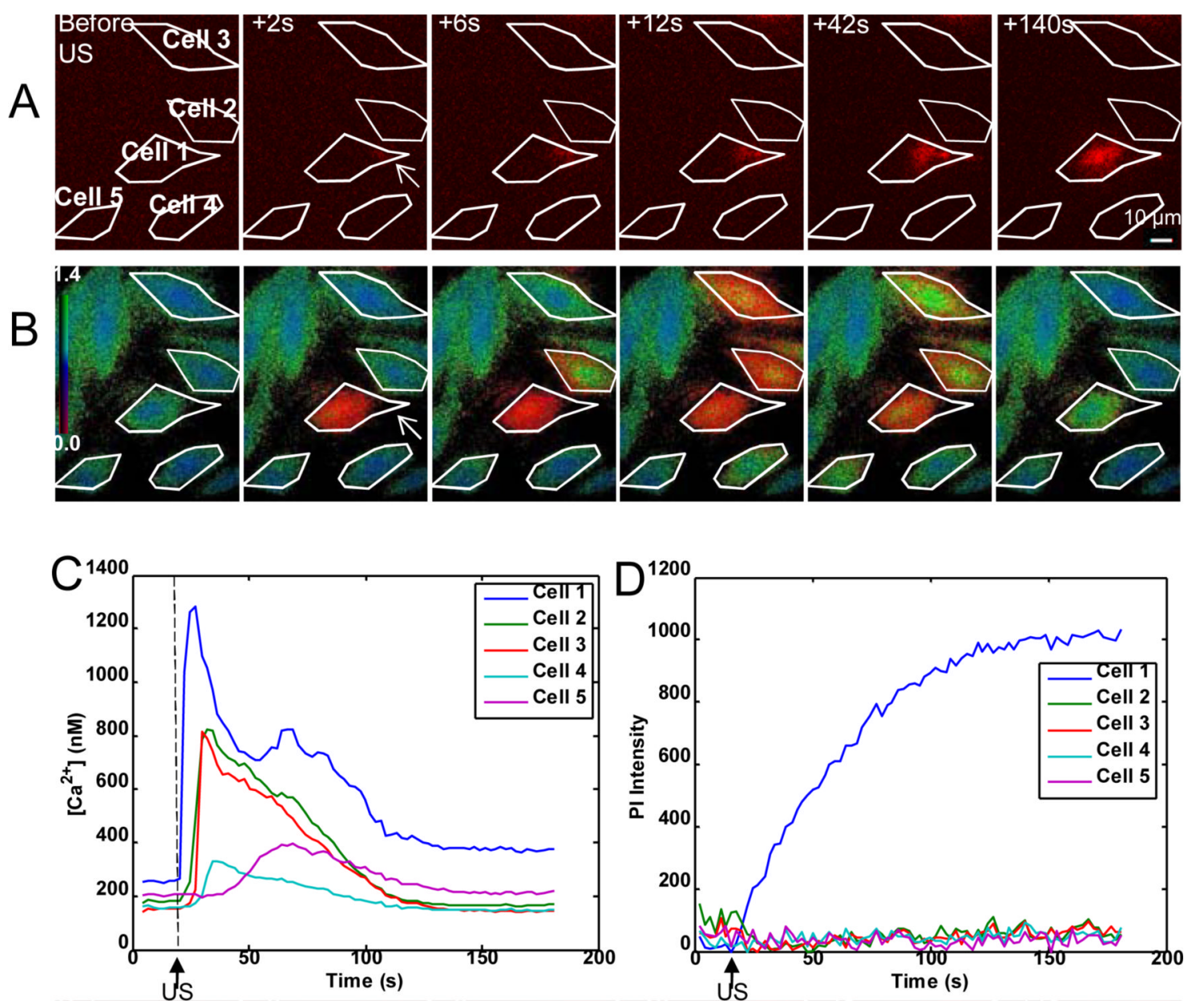

Figure 5.

(A) Time-lapse sequence of PI fluorescence images and (B) time-lapse sequence of psuedocolor $\left[\mathrm{Ca}^{2+}\right]_{\mathrm{i}}$ images for five cells, where the color bar in row B indicates the $\left[\mathrm{Ca}^{2+}\right]_{\mathrm{i}}$ in mM. Only Cell 1 (arrow) shows immediate $\left[\mathrm{Ca}^{2+}\right]_{\mathrm{i}}$ change at the time of ultrasound and immediately PI uptake are seen in only cell 1 (arrow pointed). Cells 2 to 5 show delayed $\left[\mathrm{Ca}^{2+}\right]_{\mathrm{i}}$ transients without any PI uptake. (C) $\left[\mathrm{Ca}^{2+}\right]_{\mathrm{i}}$ as a function of time for Cells $1-5$, showing the immediate change in calcium (cell 2) and delayed calcium change (cells 2-5). The $\left[\mathrm{Ca}^{2+}\right]_{\mathrm{i}}$ returned to a higher level than initial $\left[\mathrm{Ca}^{2+}\right]_{\mathrm{i}}$ for Cell 1 , while all the delayed cells returned to approximately their initial level. (D) PI intensity change as a function of time for Cells 1-5. Only Cell 1 shows any PI uptake. 


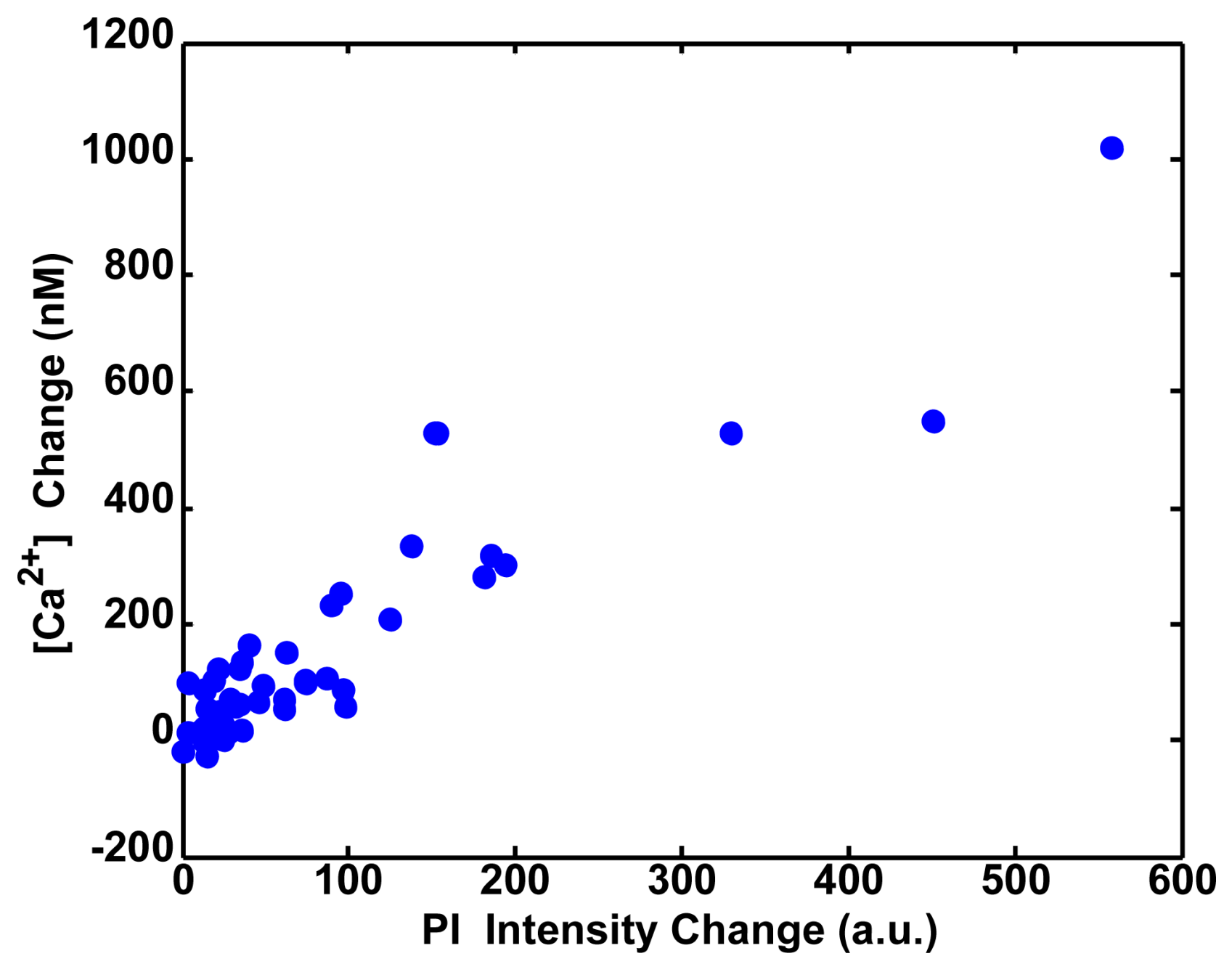

Figure 6.

Scatterplot of $\left[\mathrm{Ca}^{2+}\right]_{\mathrm{i}}$ change and PI intensity change, both at 5 min since the start of fluorescence imaging for 36 cells, showing positive correlation $(R=+0.91)$. In each case, the cells are exposed to a single $15 \mu$ s tone burst of ultrasound starting at $50 \mathrm{~s}$ after the start of fluorescence imaging. 

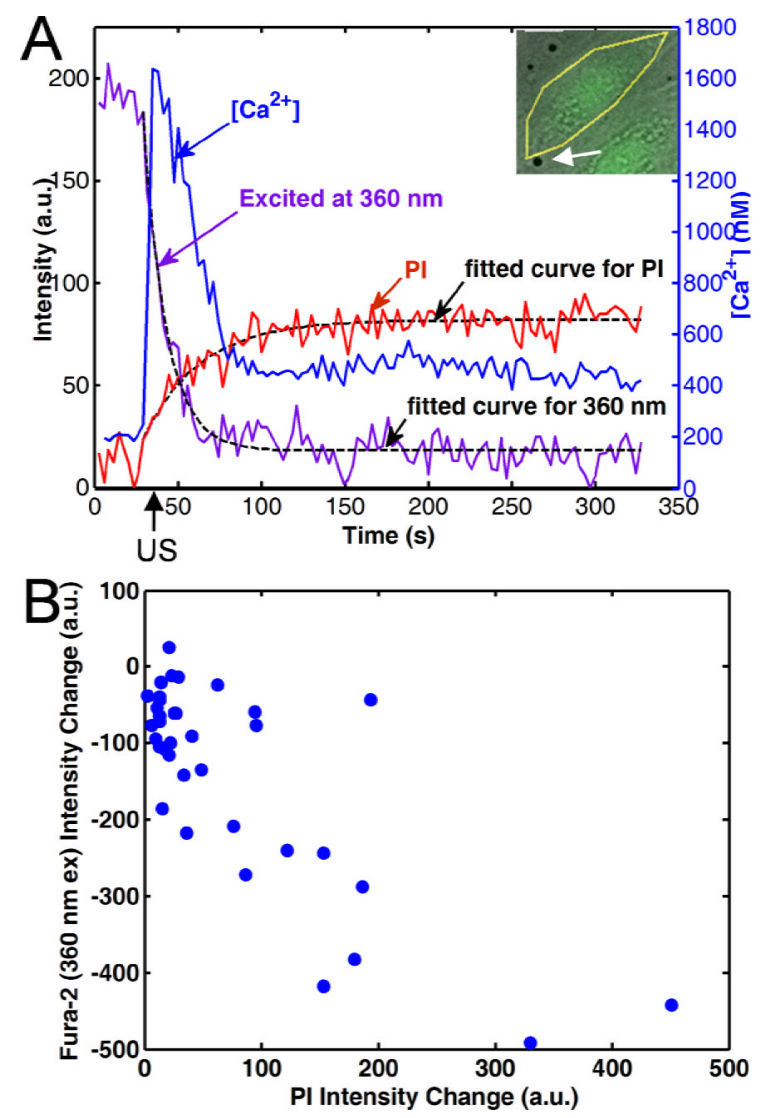

Figure 7.

Pore generation is corroborated by simultaneous PI uptake, $\left[\mathrm{Ca}^{2+}\right]_{\mathrm{i}}$ increase, and fura- 2 dye loss. (A) Changes in PI fluorescence intensity, $\left[\mathrm{Ca}^{2+}\right]_{i}$, and fura- 2 fluorescence intensity from excitation at $360 \mathrm{~nm}$ as a function of time, as induced by ultrasound-driven microbubbles for the cell shown in the inset (arrow pointing to microbubble), indicating increase in $\left[\mathrm{Ca}^{2+}\right]_{\mathrm{i}}, \mathrm{PI}$ uptake, and fura- 2 dye loss generated by ultrasound application. Dashed lines show fitting of PI uptake and fura-2 loss to exponential recovery or decay models. (B) The change of fura-2 intensity from excitation at $360 \mathrm{~nm}$ and change of PI intensity change, both at 5 min since the start of fluorescence imaging for 36 cells are negatively correlated $(R=-0.78)$, indicating loss of fura-2. 